\title{
Communities, Boundaries and New Neighbours: the Discursive Construction of EU Enlargement
}

\author{
Giuditta Caliendo \& Antonella Napolitano
}

\begin{abstract}
The institutional discourse of the European Union (EU) is undergoing important changes that are also reflected by new initiatives in its communication policy. Against a background of widespread scepticism towards EU enlargement among the public, this change is driven by the need to promote the widening of its borders in a more effective way in order to prompt popular endorsement. Through the use of its textual and visual communicative strategies, the EU is thus finding new ways to buttress its legitimacy and raise consensus around its political actions. The node of interaction between citizens and institutions is represented by the informative publications of the EU (also made available on the EUROPA website), which become a constitutive element in building Union-to-citizen communication. The analysis of textual and visual formulations of the European Commission's key booklets on EU enlargement in the period from 2004 to 2007 - in terms of their content and pragmatic aims - reveals the emergence of new consensus-building strategies. Results show that a sense of allegiance and belonging attributed to a deepening of European integration is now increasingly linked to the practical advantages of EU enlargement, as expressed through the use of 'promotional' and strategic discursive practices. Moving away from a merely informative content, communication modes 'migrate' towards a more direct and 'commodified' type of message, while an increase in visual elements plays a complementing role in promoting legitimacy and a feeling of mutual belonging between 'old' and 'new' members of the European family.
\end{abstract}

AGAINST A BACKGROUND OF GROWING PUBLIC SCEPTICISM TOWARDS FURTHER EU enlargement, this article sets out to investigate the discursive practices enacted by EU institutions to foster consensus among EU citizens. Through a case-study based on the selection of the European Commission's informative publications, a linguistic and semiotic analysis explores the ways enlargement is presented and 'promoted' via the institutional channels of Union-to-citizen communication.

Within the framework of EU enlargement, mapping out both geographical and symbolic boundaries becomes a parallel process. The extension of geographical frontiers necessarily implies the inclusion of new peoples in the European community, and a subsequent 're-assessment' of the newly co-existing communities. In the process of widening its frontiers, the discursive strategies deployed by the EU to gain consensus are informative in nature, as they focus mainly on disseminating complete and transparent information on EU policies. However, they are also grounded on persuasive discursive practices designed to foreground the benefits that enlargement brings about. This strategic synergy is aimed at gaining legitimacy, which represents an important constituent of any successful policy, as also suggested by Weber (1964: 325):

The authors discussed and conceived the article together. Namely, Giuditta Caliendo is responsible for the sections: Corpus and aims, Methodological framework, Debating enlargement, Legitimising a "fast", "costly" and "dangerous" enlargement process, Conclusions; Antonella Napolitano is responsible for the sections: Introduction, Promoting enlargement, An ever closer and visual Europe.

ISSN 1815-347X online. Caliendo, G. and Napolitano, A. (2008). 'Communities, Boundaries and New Neighbours: the Discursive Construction of EU Enlargement', Journal of Contemporary European Research, Vol. 4, No. 4, pp. 322-345. Available:

http://www.jcer.net/ojs.index.php/jcer/article/view/128/115 
"Every system of authority attempts to establish and to cultivate the belief in its legitimacy".

The EU has long understood the growing need to strengthen its legitimacy and public endorsement ${ }^{1}$. Hence, the efforts to promote a sense of aggregation which finds expression in the dissemination of information through a wide range of channels, including traditional media and new communication technologies, such as the Internet. All informative publications on EU enlargement which constitute the corpus of this study are made available to the public both in paper and electronic versions through the EU's official EUROPA website ${ }^{2}$.

Guaranteeing up to date and transparent communication is linked directly to the idea of fostering citizens' involvement in EU affairs and policies, as also stressed by the White Paper on a European Communication Policy (European Commission 2006b) whose adage goes "Debating Europe, Involving Europe":

Over the last two decades, the European Union has been transformed. It has taken on a wide range of tasks touching citizens' lives in many different ways. But Europe's communication with its citizens has not kept pace. The gap between the European Union and its citizens is widely recognised. In Eurobarometer opinion polls carried out in recent years, many of the people interviewed say they know little about the EU and feel they have little say in its decision-making process. Communication is essential to a healthy democracy. It is a two-way street. Democracy can flourish only if citizens know what is going on, and are able to participate fully. (European Commission 2006b: 2) [italics added]

In the case of EU enlargement, Union-to-citizen communication is instrumental to the achievement of consensus and citizens' participation, especially against a backdrop of widespread distrust about the process. The research work thus sets out to explore the legitimating role played by language in this respect: "Language is more than a medium of expression, it forms reality, including political reality in the sense of both positive and negative images, norms, and evaluations" (Karklins 2001).

\section{Corpus and aims}

The full range of publications available in the enlargement section of the EUROPA website $^{3}$ consists of the documents listed in Table 1 (see page 324):

The documents display a varied level of technicality, evidently as a communication strategy aimed at reaching the audience at all possible levels of interaction. They can be largely divided into two main categories:

- simple informative leaflets, consisting of one single sheet of paper folded but not stitched;

- booklets, consisting of small-sized brochures of up to 15-25 pages. These can be further divided into: specialised booklets, aimed at the technically-minded; more general and reader-friendly booklets of a popularizing nature, relying on a wider use of visuals as much as on a more direct and dialogic communication strategy.

\footnotetext{
1 The European Commission clearly outlined the problem of democratic deficit in its White Paper on a European Communication Policy (European Commission 2006b: 2). In this respect, one of the numerous initiatives undertaken to tackle the issue is represented by the establishment of the DEBATE EUROPE online forum, available at: http://europa.eu/debateeurope/index en.htm, last accessed 22 December 2008).

${ }^{2}$ The EU's official online portal, www.europa.eu last accessed 22 December 2008.

${ }^{3}$ Available at: http://ec.europa.eu/enlargement/press corner/index en.htm, last accessed July 2008.
} 
Table 1: EU publications on Enlargement in order of publication date

\begin{tabular}{|l|c|}
\hline \multicolumn{1}{|c|}{ Title of publication } & $\begin{array}{c}\text { Text } \\
\text { type }\end{array}$ \\
\hline $\begin{array}{l}\text { Understanding enlargement. Explaining EU policy on enlargement for the } \\
\text { general public (2007) }\end{array}$ & Booklet \\
\hline Studying in Europe. EU Scholarships for Western Balkan Students (2007) & Leaflet \\
\hline 20 Myths and Facts about the Enlargement (2006) & Booklet \\
\hline $\begin{array}{l}\text { Regional cooperation in the western Balkans. A policy priority for the } \\
\text { European Union (2006) }\end{array}$ & Booklet \\
\hline $\begin{array}{l}\text { Where to find information on the Acceding States, Candidate and } \\
\text { Potential Candidates Countries (2006) }\end{array}$ & Leaflet \\
\hline $\begin{array}{l}\text { Enlarging the European Union: from 15 to 25, what does it mean for us? } \\
\text { (2005) }\end{array}$ & Booklet \\
\hline Twinning (2005) & Booklet \\
\hline European Union Enlargement - An historic opportunity (2003) & Booklet \\
\hline EU support for Roma communities in Central and Eastern Europe (2003) & Booklet \\
\hline $\begin{array}{l}\text { What can enterprises in the new Member States expect? Questions and } \\
\text { answers (2003) }\end{array}$ & Booklet \\
\hline Free movement of persons / Practical guide for an enlarged EU (2003) & Booklet \\
\hline $\begin{array}{l}\text { Dialogue and Information Newsletter Nr. 4/2004, Nr. 3/2004, Nr. 2/2003, } \\
\text { Nr. 1/2003 }\end{array}$ & Booklet \\
\hline European Union Enlargement - An historic opportunity (2002) & Booklet \\
\hline
\end{tabular}

Source: European Commission website. Available at:

http://ec.europa.eu/enlargement/press corner/publications/index en.htm, last accessed July 2008.

The selection of the corpus of documents for the analysis was based on some 'exclusion' criteria, omitting the following types of publications:

- Leaflets, as they provide an information load which is insufficient for the purpose of linguistic analysis. These texts often represent a mere list of information concerning specific documentation centres operating at national level (e.g. "Where to find information on the Acceding States, Candidate and Potential Candidates Countries" 2006), or specific EU programmes and scholarship schemes (e.g. "Studying in Europe. EU Scholarships for Western Balkan Students" 2007).

- Booklets specifically focusing on issues pertaining to: individual acceding or aspiring countries (e.g. "EU support for Roma communities in Central and Eastern Europe" 2003; "Regional cooperation in the western Balkans. A policy priority for the European Union" 2006); restricted addressees, such as enterprises (e.g. "What can enterprises in the new Member States expect? Questions and answers" 2003).

- Booklets consisting of practical guides on specific policies (e.g. workers' mobility rights in the publication "Free movement of persons / Pratical guide for an enlarged EU" 2003), or on financial assistance programmes aimed at preparing candidate countries for accession (e.g. "Twinning" 2005).

- Booklets centred on more technical aspects of the enlargement policy (i.e. Europe agreements, association agreements, budgetary arrangements, co-financing with the EIB, trade and export/import with candidate countries, foreign direct investment, etc.), supported by detailed and specialised data, charts and information, and aimed at a more specialised readership (e.g. "European Union Enlargement - An historic opportunity" 2002).

- The four "Dialogue and Information Newsletters" (European Commission Nr. 4/2004, Nr. 3/2004, Nr. 2/2003, Nr. 1/2003), as they are a set of publications which fall within The Phare Networking Facility Programme. Each newsletter specifically addresses social issues such as drugs, disabled citizens and disadvantaged minorities. 
For the purpose of this study, the selected corpus of documents is thus limited to the three EU official publications on enlargement aimed at a general readership:

Table 2 : Description of selected EU documents used for linguistic analysis

\begin{tabular}{|c|c|c|c|}
\hline \multicolumn{2}{|r|}{ Title } & \multirow{2}{*}{$\begin{array}{c}\begin{array}{c}\text { Date of } \\
\text { publication }\end{array} \\
2004\end{array}$} & \multirow{2}{*}{$\begin{array}{c}\begin{array}{c}\text { Number } \\
\text { of } \\
\text { tokens }\end{array} \\
1,095\end{array}$} \\
\hline 1. & $\begin{array}{l}\text { Enlarging the European Union: from } 15 \text { to } 25 \text {, what } \\
\text { does it mean to us? }\end{array}$ & & \\
\hline 2. & 20 Myths and Facts about the Enlargement & 2006 & 3,462 \\
\hline 3. & $\begin{array}{l}\text { Understanding enlargement. Explaining EU policy on } \\
\text { enlargement for the general public }\end{array}$ & 2007 & 3,486 \\
\hline
\end{tabular}

Source: European Commission website. Available at:

http://ec.europa.eu/enlargement/press corner/publications/index en.htm, last accessed July 2008

These texts provide an interesting insight into EU discourse on the status quo of the enlargement process. The diachronic investigation is aimed at demonstrating shortterm changes in 'communicating enlargement' to the general public, to the extent that each of the above documents was issued after an important date in the recent history of the EU and has affected the public perception of its widening process, respectively:

1. the 2004 "Big Bang" enlargement (European Commission 2006a: 2), when ten new countries from central Europe and the Mediterranean joined ${ }^{5}$;

2. the 2005 failure of the national referenda on the Treaty establishing a Constitution for Europe in France and the Netherlands;

3. the EU accession of Bulgaria and Romania in January 2007.

The above events are therefore considered within the social and political frame in which they are embedded, and analysed discursively in this paper. Taking into account the contrasting feelings that citizens hold about these events, as well as the different historical and socio-political contexts of reference, the documents are investigated to detect and unveil the linguistic strategies deployed by the institutions to construct enlargement as a positive, fruitful and 'legitimate' move towards closer integration of the peoples of Europe. In pursuing this aim, the construction of legitimation in discourse is critically analysed, also drawing upon the categories explored by critical discourse analysts.

\section{Methodological framework}

The study draws on Critical Discourse Analysis (CDA) in order to investigate the linguistic elements contributing to the discursive construction of EU enlargement as a necessary and legitimate process. As maintained by Fairclough (1992: 8), institutional and social structures are shaped by discourse, which does not just reflect or represent society, but also "helps to constitute (and change) knowledge and its objects, social relations and social identity". In particular, this article refers to the constructive, perpetuating and transformational macrofunctions of discourse, i.e. the way discursive acts play a decisive role in generating, reproducing and transforming a given status quo (Van Leeuwen and Wodak 1999).

\footnotetext{
${ }^{4}$ In Corpus Linguistics, every token is represented by the individual occurrence of a linguistic unit.

5 The Member States which joined the EU in May 2004 are: Czech Republic, Estonia, Latvia, Lithuania, Slovenia, Slovakia, Poland, Hungary, Cyprus and Malta.
} 
Furthermore, CDA literature provides an inspiring framework with reference to instances of legitimation for social practices in public communication. In their approach to political discourse, Chilton and Schäffner (1997: 211-215) list legitimation among the four "strategic functions" that linguistic expressions may be used for. These include (1) coercion; (2) resistance/opposition/ protest; (3) dissimulation; and (4) legitimisation/delegitimisation. According to Chilton (2004: 47), legitimation is oriented towards acts of self-representation and self-praise as a source of "authority, reason, vision and sanity, where the self is either an individual or the group with which an individual identifies or wishes to identify". This concept is further enriched by Cap (2005: 4-5):

\begin{abstract}
Drawing on the Habermasian epistemological framework and his account of rationality and 'rightness' (Richtigkeit) in particular (cf. Habermas 1981), this definition takes up both the socio-political and the linguistic aspect of the speaker's performance. The claim to rightness and the resulting enactment of legitimization means that the performing of speech acts is grounded in an implicit claim, on the part of the speaker, to inhabit a particular social or political role, and to possess a particular authority.
\end{abstract}

Legitimation and consensus-building strategies in the area of EU discourse have been dealt with by previous scholars, with reference to various aspects of EU policy and government, from negotiations of the EU Constitution (Krzyżanowski and Oberhuber 2007) to EU identity and representation (Wodak and Weiss 2004, 2005). The present article contributes to this field of study by focusing on legitimation vis-à-vis EU enlargement. In doing so, the analysis particularly refers to the work of Van Leeuwen (1996; 2007) who, drawing on Habermas (1976), Weber (1964) and Berger and Luckmann (1967), develops a set of legitimation categories (and relevant sub-types), which elucidate the various textual strategies used to claim rightness and authority. Van Leeuwen's perspective is applied here to reveal and discuss the discursive structures enacted by the EU in promoting enlargement to its citizens.

The analysis of visual elements also plays a key role in the study. Starting from the theory according to which "discourse reaches out further than language itself" (Jaworski and Coupland 2006: 7), CDA extends its analysis to include other semiotic systems and dimensions. Investigating non-verbal discourse and visual images in particular, therefore becomes part and parcel of the linguistic analysis itself. As Phillips and Jorgensen (2002: 61) point out: "within critical discourse analysis (as discourse analysis in general) there is a tendency to analyse pictures as if they were linguistic texts". Since the informative content of the EU brochures under investigation is conveyed both by verbal formulations and visual images, this article also draws on the methodological framework on multimodal representation and visual grammar to produce a comprehensive analysis. All visual media compositions are devised to communicate intended meaning and create a desired effect. This results in a visual language which can be analysed in the light of the theory of multimodality. The grammar of visual design thus explores the way in which people, places and things are depicted and combined into a meaningful whole, with a view to investigating and interpreting the important role played by 'visual statements' in contemporary institutional discourse: "Just as grammars of language describe how words combine in clauses, sentences and texts, so our visual grammar will describe the way in which depicted people, places and things combine in 'visual statements' of greater or lesser complexity and extension" (Kress and Van Leeuwen 1996: 1).

With reference to images, the qualitative analysis also pays great attention to the contribution of metaphors in the social construction of reality (Berger and Luckman 1967), be it social, political or economic. Our conceptual system is considered to be "fundamentally metaphorical in nature" (Lakoff and Johnson, 1980: 3). Metaphors thus operate on a cognitive level in revealing mechanisms of social change, as argued by Charteris-Black (2004: 251): metaphor is a way of creating cognitive meaning, "by changing the metaphor we may change the way that we think and feel about something". In this respect, metaphorical images and visual associations relating to the 
process of enlargement are also explored in the analysis, together with discursive practices aimed at conveying the idea of enlargement as an ongoing, open-ended and necessary process, though democratically endorsed by all EU actors through the mechanisms of EU conditionality and requirements for accession of applicant countries.

This contribution also takes into consideration studies in the field of sociology since "the complex interrelations between discourse and society cannot be analysed adequately unless linguistic and sociological approaches are combined" (Wodak and Weiss 2005: 124). The EU is therefore conceived "in a sociological sense", i.e. "characterised as an institution, a polity, operating at a macrosocietal level" (Laffan 2004: 76; 78).

\section{Promoting enlargement}

The publication of the first document under investigation, "Enlarging the European Union: from 15 to 25, what does it mean to us?" (European Commission 2004), followed the biggest enlargement round in the history of the European Union. This first document opens with a short introductory paragraph followed by five other descriptive ones, each based on a question-answer format. Information about the repercussions and consequences of the enlargement process is given in response to an imaginary 'input': direct questions posed by a hypothetical inquisitive reader, who becomes an interlocutor in the dialogue with the institutions in order to find out what enlargement will eventually lead to.

This first document is developed entirely around six key questions, including the title of the publication itself:

- Enlarging the European Union: from 15 to 25, what does it mean to us?

- What does enlargement mean for the 'former' Member States (EU 15)?

- What is the impact of enlargement on daily life?

- What effect will enlargement have on the EU institutions?

- Are there limits to enlargement?

- What about the new neighbours of the enlarged Union?

In spite of the overall informative tone of this booklet, the question form employed here is a recurring pattern in promotional discourse: it immediately suggests inclusion and dialogic interaction with the reader, whose questions and doubts are being answered by the presentation of precise data.

The incursion of a discourse type typical of advertising and of seller/customer practices into institutional discourse can be related to the linguistic processes of "interdiscursivity" and "commodification" explored by Fairclough (1992: 10-11): "Commodification is the colonization of institutional orders of discourse, and more broadly of the societal order of discourse, by discourse types associated with commodity production" (Fairclough 1992: 207).

The so called 'big-bang' enlargement in 2004 was an utterly remarkable event that aroused curiosity and reservations among citizens as to its potential consequences. Against this historical background, the document centres mainly on the descriptions of the status quo, contributing to the belief that enlargement has so far represented a unique and indisputable success. More specifically, the description of enlargement in the 2004 text is celebratory in tone and overtly 'promoting' an unprecedented achievement: 
(1) This enlargement is a unique achievement. ${ }^{6}$ (European Commission 2004: 1)

(2) The first of May 2004 represents an historic and unprecedented milestone in the development of the European Union (EU). (European Commission 2004: 1)

Constant reference to facts, data and percentages throughout the document increases the 'evidentiality' of EU enlargement's concrete and positive results:

(3) With a population of 450 million, the Union now represents the largest internal market in the world; this enlarged Single Market accounts for some $19 \%$ of world trade. (European Commission 2004: 1)

(4) The accession of 10 new countries is expected to lead to an increase of the EU25's overall gross domestic product (GDP) by 4-5\%, while at the same time reducing the average GDP per capita to $92 \%$ of the former EU15. (European Commission 2004: 1)

The self-praising tone is also achieved by the use of comparatives and superlatives, stressing the exceptional and unparalleled results that have become a reality through enlargement:

(5) The new Member States will enrich the EU with their wealth of different cultures, traditions, heritage and languages. So the Union is bigger and better for their joining us. (European Commission 2004: 2)

(6) Increased competition should also be positive for European consumers in terms of prices, variety and quality of supply of goods and services, while also ensuring a consistent, higher degree of consumer protection. (European Commission 2004: 1)

(7) There will also be a better quality of life through common EU policies for the protection of the environment, and more security for all European citizens through joint efforts in the fight against crime, drugs and illegal immigration. (European Commission 2004: 2)

(8) From now on, all EU citizens will be able to live, travel, work and study with greater ease throughout a territory that stretches from the Baltic Sea to the Eastern Mediterranean (European Commission 2004: 3)

The overall style of the publication recalls the discourse of advertising for the promotion of products which "require a certain level of explanation"; this style, referred to as "advermation" (Shortis 2001: 24), is defined as a blend of information and persuasion. The evaluative claims of "advermation" often relate to the desirable aspects of the items being promoted and accomplish the double aim of encouraging 'purchase' and disseminating information. Like a promotional text, the document also abounds in expressions which echo promotional catch phrases, according to which EU Enlargement represents:

- an "unprecedented milestone" (European Commission 2004: 1)

- a "unique achievement" (European Commission 2004: 1)

- a "commitment to promoting the prosperity of our continent through peace, security, solidarity and stability for all its citizens" (European Commission 2004: 1)

- an "end to the division of our continent" (European Commission 2004: 1)

- a "safer legal environment" (European Commission 2004: 1)

\footnotetext{
${ }^{6}$ All italics used in examples 1-57 have been added by the authors.
} 
- the possibility to "live, travel, work and study with greater ease throughout a territory that stretches from the Baltic to the Eastern Mediterranean" (European Commission 2004: 2).

Nouns, adjectives and verbs used in the booklet all contribute to the description of enlargement as a 'captivating product' that everybody would wish for and aspire to. The enlargement will provide for whatever priority European citizens might have: freedom, human rights, mobility of workers, equal opportunities, safer food, safer environment and better quality of life. In particular, the verbs used in the booklet give voice to the "transformative power" of this unprecedented and unique enlargement (Caliendo and Balirano [forthcoming]), which will enhance, improve, strengthen or enrich any possible field of work of the European Commission, from competition to global governance:

(9) The extension of the zone of peace, stability and prosperity that the EU has brought to Europe will enhance the security of all its peoples. (European Commission 2004: 1)

(10) However, this loss in GDP should quickly be compensated for by the implementation of the Single Market rules and improved market access for business, which are expected to lead to increased efficiencies through greater competition. (European Commission 2004: 1)

(11) The Union's role in world affairs - in foreign policy, citizen protection, trade policy, and other fields of global governance - will be strengthened. The new Member States will enrich the EU with their wealth of different cultures, traditions, heritage and languages. (European Commission 2004: 2)

(12) At the end of the transitional period (see below) on freedom of movement of workers, people from across Europe will be able to reap the benefit of improved employment policies by increasing labour skills, labour market flexibility, mobility of workers, business climate, adaptation to new technologies and equal opportunities. (European Commission 2004: 2)

In the 2004 brochure, the presence of visual images extends the meaning of the verbal text and confirms the 'promotional' inclination of the document. In describing how the language of advertising, pervaded by visual imagery, is spreading to many public domains, Fairclough $(1989 ; 1992)$ highlights the incursion of the visual into various fields of public and institutional communication, where verbal language used to be the sole and dominant mode.

In relation to the four images in the booklet, the house represents the overall dominant visual metaphor. The EU is symbolised by a large, spacious house with windows and doors wide open and encircled by an open fence, all of which evokes willingness to enlargement and dialogue with neighbouring countries

As shown in Figure 1, some smaller houses are lined up along the outer limits of the fence, clearly hinting at the EU's neighbourhood policy, which is aimed at creating a political and social framework to share "the EU's fundamental values and objectives". (European Commission 2004: 4). 
Figure 1: "A European neighbourhood policy to share the EU fundamental values and objectives"

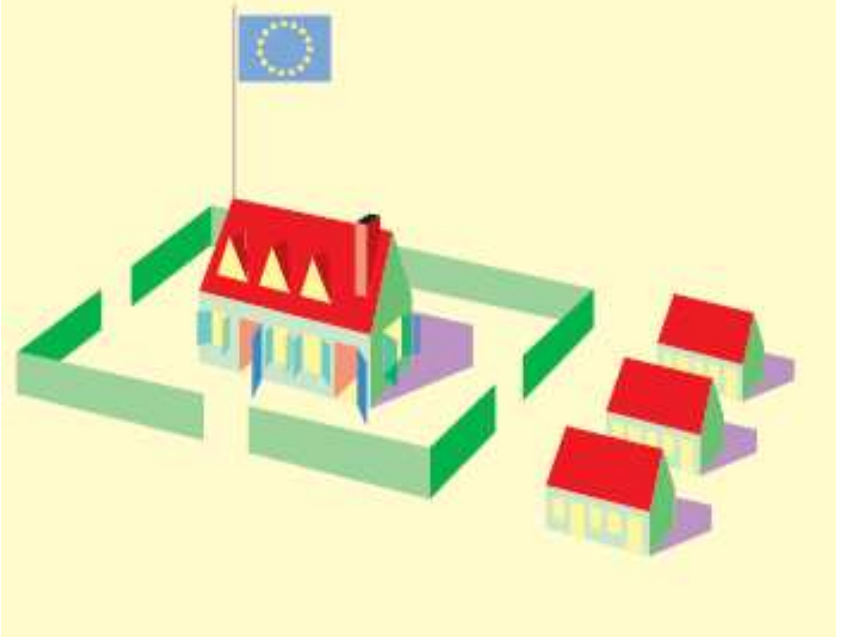

Source: "Enlarging the European Union: from 15 to 25, what does it mean for us?" (European Commission 2004: 4).

In Figure 2 the EU house is portrayed with its windows and doors wide open and placed at a crossroad, which evidently represents openness and the opportunities being offered to any acceding country. Next to the house there is nothing but the EU flag, which stresses the idea of a single unifying emblem and, as the caption of the 2004 booklet reads, the compliance with "EU standards applied in all 25 Member States for a better quality of life". (European Commission 2004: 2).

\section{Figure 2: "EU standards applied in all 25 Member States for a better quality of life"}

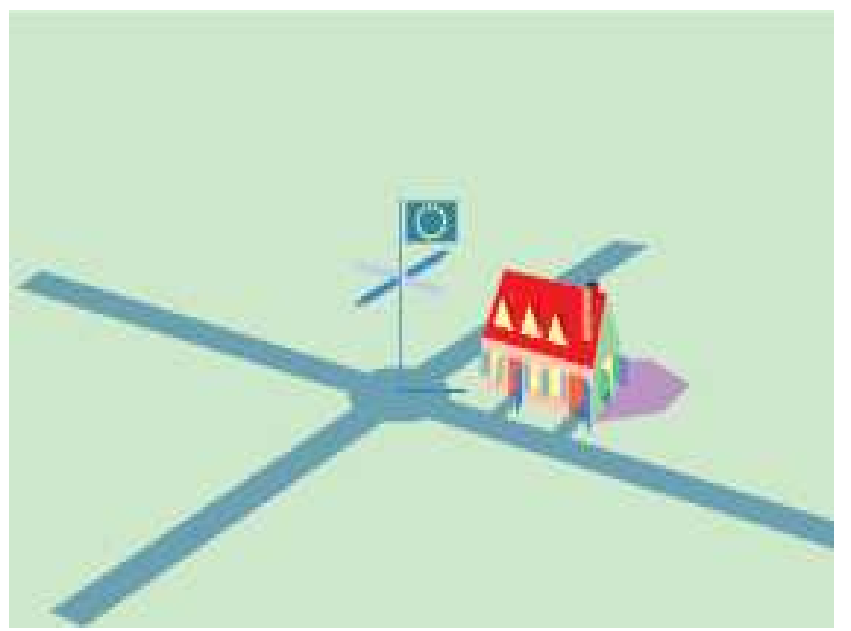

Source: "Enlarging the European Union: from 15 to 25, what does it mean for us?" (European Commission 2004: 2).

On the whole, text and images both aim at stressing the in fieri nature of the EU project, which is also evident from the very first picture chosen for the booklet cover: a long row of houses, each with the flag representing a member state; at the end of the line lies a symbolic house under construction, alluding to the ongoing work that is leading to a larger EU: 
Figure 3: Front cover

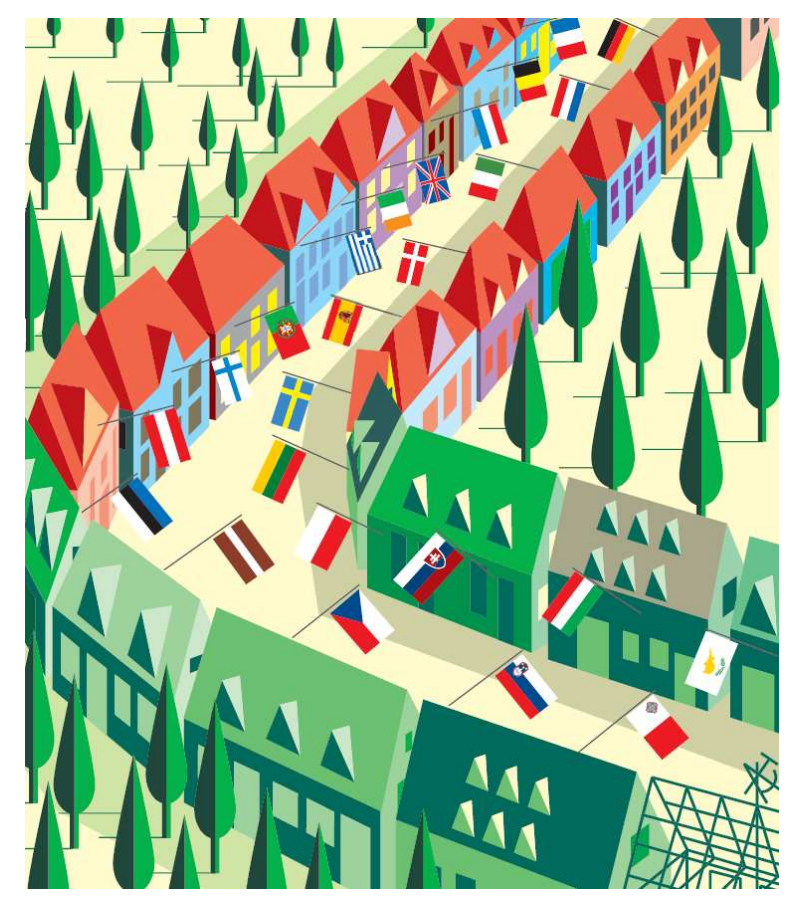

Source: "Enlarging the European Union: from 15 to 25, what does it mean for us?" (European Commission 2004: front cover).

At the dawn of the first big enlargement round, the EU was seeking to establish a trusting relationship with its citizens. The need to inform them, as well as to infuse enthusiasm, is conveyed through discursive practices which are both informative and promotional and which also encompass other forms of semiosis, such as visuals. The EU reconstructs its readers as consumers (Fairclough 1994) and adopts linguistic strategies typical of advertising discourse. This process, known as commodification, has been thoroughly explored by Fairclough (1994: 253), who defines it as the "weakening of boundaries between, on the one hand, the discursive practices of the market in the more traditional sense, and on the other hand the discursive practices of politics, public services, [...] government and other forms of public information [...]".

\section{Debating enlargement}

In 2006, the European Commission's Directorate-General for Enlargement commissioned a poll on EU citizens' perception of enlargement and its relevant advantages/disadvantages (European Commission 2006c: 2). Although the picture varied from country to country, the opinion poll showed that attitudes towards further enlargement had become significantly more negative after the 2004 accessions ${ }^{7}$ :

Table 3: Growing negative attitudes towards further EU enlargement (2004-2006)

\begin{tabular}{|l|c|c|c|}
\hline & Autumn 2004 & Autumn 2005 & Autumn 2006 \\
\hline Against EU enlargement & $35 \%$ & $39 \%$ & $42 \%$ \\
\hline
\end{tabular}

Source: Eurobarometer, Full report 62 of Autumn 2004 (European Commission 2005c: 152), Full report 64 of Autumn 2005 (European Commission 2006d: 134), Full report 66 of Autumn 2006 (European Commission 2007b: 218).

7 Data available at: http://ec.europa.eu/public_opinion/standard_en.htm (last accessed November 2008). 
Following the failure of the referendum on the Treaty establishing a Constitution for Europe in France and the Netherlands in 2005, people started to question the EU enlargement policy and express perplexities as to the future expansion of EU borders. The 2006 and 2007 documents under investigation - respectively, "20 Myths and Facts about Enlargement" (European Commission 2006a) and "Understanding Enlargement" (European Commission 2007a) - can be viewed as a reaction to those public concerns. They also reflect changes in the EU communication strategy: the more defensively explicative language of the 2006 publication seems to be aimed deliberately at countering criticism and misconceptions about the enlargement process. The former 'promotional' tone of the 2004 document is thus marginalised in favour of linguistic choices which are more typical of an 'after sales' discourse.

In the opening statement of the brochure, the European Commission directly acknowledges a deficit in public endorsement vis-à-vis enlargement. The stated aim of the communication initiative itself is to address citizens' concerns with appropriate reasons and motivations:

(13) A carefully managed enlargement process extends peace, democracy, the rule of law and prosperity across Europe. However, many EU citizens now question the grounds of enlargement. While addressing the citizens' concerns with appropriate policies, myths should be countered by facts, which is the aim of this note. (European Commission 2006a: 1)

(14) For any of its policies, including enlargement, the EU has to win the support of its citizens. Both the member states and the EU institutions need to communicate the successes and challenges of enlargement better. (European Commission 2006a: 3)

The whole 2006 document is built around twenty questions grouped into six main thematic areas: (i) rapidity, (ii) weakness, (iii) expensiveness and (iv) dangerousness of the enlargement process; ( $v$ ) excessive number of the countries involved; (vi) potential benefits. As in the previous publication, the questions are posed by an 'imaginary' interlocutor. The communicative exchange is based on a dichotomised framing: a negative claim in the form of a question (expressing citizens' doubts and suspicions) versus a counterclaim (the assertions put forward by the institutional reply).

Table 4: Question-answer patterns in "20 Myths and Facts about Enlargement"

\begin{tabular}{|l|l|}
\hline \multicolumn{1}{|c|}{ Questions } & \multicolumn{1}{c|}{ Counterclaims } \\
\hline Too fast? & The 2004 enlargement was the best prepared in the history of the EU. \\
\hline Too weak? & $\begin{array}{l}\text { The history of the EU proves that there is no contradiction between widening } \\
\text { the Union and deepening its integration. The EU has managed to do both. }\end{array}$ \\
\hline Too costly? & $\begin{array}{l}\text { A cup of coffee a month is the price that each citizen of the old member states } \\
\text { has paid for helping to reunite Europe [...]The money spent to help develop } \\
\text { these economies creates new business opportunities in old and new member } \\
\text { states alike. }\end{array}$ \\
\hline Too dangerous? & $\begin{array}{l}\text { Enlargement enables the EU to extend its police and justice cooperation to } \\
\text { the new member states, thus making the fight against crime and terrorism } \\
\text { more effective. }\end{array}$ \\
\hline Too many? & $\begin{array}{l}\text { The EU Treaty says that any European country which respects the values of } \\
\text { democracy, human rights and the rule of law may apply for EU membership. } \\
\text { However, this does not mean that all European countries must apply [...] The } \\
\text { EU's borders are defined by decisions taken unanimously at the highest } \\
\text { political level. }\end{array}$ \\
\hline $\begin{array}{l}\text { Even } \\
\text { benefit? }\end{array}$ & $\begin{array}{l}\text { First and foremost, we all benefit from the increased stability and peaceful } \\
\text { development to which the successive enlargements of the EU have } \\
\text { contributed over the years [...] Citizens can benefit from enlargement in many } \\
\text { other ways, such as by easier travel, better chances to study abroad, and } \\
\text { better business conditions. }\end{array}$ \\
\hline
\end{tabular}

Source: “20 Myths and Facts about Enlargement” (European Commission 2006a: 2-15). 
As displayed in table 4 (see above), every single negative element contained in the introductory elliptic questions of the six thematic areas is counterbalanced by a defensive answer, which is aimed at reassuring citizens on all the possible negative repercussions that they fear enlargement may trigger.

The twenty main questions which constitute the structure of this booklet are no longer enquiring in nature, but critical, straightforward and implicitly disapproving of the enlargement process:

(15) When will it all stop? Shouldn't we fix the borders of the EU once and for all? (European Commission 2006a: 12)

(16) Will there be another big bang enlargement soon? (European Commission 2006a: 2)

(17) Why should we take in a non-Christian country? (European Commission 2006a: 13)

The majority of the questions are in the negative question form "Hasn't...?", "Isn't...?", "Won't...?", so as to acknowledge citizens' criticism and widespread concern about the possible negative consequences of enlargement, such as illegal immigration, instability, social dumping, and paralysis of EU functioning:

(18) Isn't it undemocratic and shouldn't the EU listen to the public opinion? (European Commission 2006a: 3)

(19) Hasn't enlargement paralysed the functioning of the EU? (European Commission 2006a: 4)

(20) Hasn't enlargement brought a flood of workers to the old Member States? (European Commission 2006a: 6)

(21) Won't enlargement prevent further deepening of the EU? (European Commission 2006a: 4)

Their tinge of discontent highlights all the possible (economic, social, political) risks that the enlargement could entail. Though the question-answer format recalls the structure of the 2004 booklet, the answers here abound in negative statements (viz. use of negative verb forms and negative prefixes), aimed at refuting and playing down the catastrophic scenario put forward in the questions:

(22) Did the 2004 enlargement go too fast?

Ten new members entered simultaneously in May 2004, but the reunification of Europe did not happen overnight. (European Commission 2006a: 2)

(23) Will there be another big bang enlargement soon?

There is no new 'big bang' on the horizon. (European Commission 2006a: 2)

(24) Hasn't enlargement paralysed the functioning of the EU?

The accession of ten new members has not slowed down decisionmaking. (European Commission 2006a: 4)

(25) Won't enlargement prevent further deepening of the EU?

The history of the EU proves that there is no contradiction between widening the Union and deepening its integration. (European Commission 2006a: 4)

(26) Hasn't enlargement brought a flood of workers to the old Member States? 
The doomsday predictions of a flood of workers from Central and Eastern Europe have proved to be unfounded. (European Commission 2006a: 6)

The wording of the 2006 text presupposes that enlargement is not a top-down imposition, but rather an indispensable achievement, a "nécessité historique" (see Krzyżanowski 2005). It is indeed portrayed as an unavoidable and 'consequential' evolution due to the 'centripetal force' of the EU and to an extraordinary process of historical, democratic and economic transformation:

(27) Over the last fifteen years, the gravitational pull of the EU has helped transform Central and Eastern Europe from communist regimes to modern, well-functioning democracies. (European Commission 2006a: 1)

(28) The countries of Central and Eastern Europe, Cyprus and Malta joined a decade and a half after the fall of the Berlin Wall. Over those 15 years, these countries achieved a profound democratic and economic transformation, which made them fit for EU membership and made Europe better off. (European Commission 2006a: 2)

(29) The history of the EU proves that there is no contradiction between widening the Union and deepening its integration. The EU has managed to do both. (European Commission 2006a: 4)

The visual aspect plays a less important role in this booklet. The distinctive sober style of the document strongly clashes with that of the previous one and its use of brightly coloured drawings. The focus here is mainly on the 'verbal dialogue' with the citizens and on the reasons why misconceptions about EU enlargement should be considered unfounded. The small number of images is limited to simple outline maps of Europe in three main chromatic nuances. The geographical names on the maps - be they EU members or aspiring candidate countries - are written in their original language. This may represent a visual hint to the EU motto "United in diversity", which first came into use around the year 2000. The motto was officially mentioned for the first time in the Treaty establishing a Constitution for Europe (European Union 2004: 3). Its meaning is effective and straightforward, underlining the fact that joining the EU does not necessarily imply the loss of Member States' individual identity.

\section{Legitimising a "fast", "costly" and "dangerous" enlargement process}

As shown in Table 3 with reference to the Eurobarometer data, in 2006 public opinion did not appear particularly favourable to the EU enlargement process. The publication "20 Myths and Facts about the Enlargement" thus marks a decisive passage from a descriptive and informative voice (as expressed in the 2004 booklet) to the discursive enactment of legitimation practices.

As anticipated in the methodology section, the strategies used by the EU in order to support and 'promote' the process of enlargement and to provide 'reasons to be listened to' are here analysed also in the light of some of the categories outlined by critical discourse analysts (Van Leeuwen 1996; Wodak and Weiss 2005). In Van Leeuwen's words, "discourses construct legitimation for social practices in public communication as well as in everyday interaction" (1996: 91).

In its 2006 publication, the European Commission portrays enlargement not as a topdown process initiated and imposed from above, but rather as a result that is democratically arrived at and which involves the active and joint participation of all political stakeholders in the decision-making process. In this respect, both enlargement and the political construction of the EU are connected to what Wodak and Weiss (2005: 
131) define as "legitimation through procedure", mainly centred on the presence of legitimizing elements, such as participation, inclusiveness and democracy:

(30) Any decision on the accession of a country has to be taken unanimously by all member states. (European Commission 2006a: 2)

(31) Every major decision leading to a country's accession is taken unanimously by the democratically elected governments of the EU member states. National parliaments have to ratify the decision. (European Commission 2006a: 3)

(32) The Members of the European Parliament, who are directly elected, have to give their assent. Thus, all the key decisions are taken by all the relevant democratically elected bodies in each member state and in the Union. (European Commission 2006a: 3)

EU enlargement is also legitimised on the basis of a set of conditions that have determined, from the outset, the history of the EU widening process. The first requirement to join the EU was set out in 1957 by the Treaty of Rome, which simply stated that "any European State may apply to become a member of the Community" (Art 237). However, increasingly, candidate countries have been subject to more and stricter membership conditions (Caliendo and Venuti 2008). In 1978, before the EU accession of Greece, Portugal and Spain - which were making a transition from authoritarian rule to democracy - the Declaration on Democracy included in the conclusions of the Copenhagen European Council established that "respect for and maintenance of representative democracy and human rights in each Member State are essential elements of membership in the European Communities" (European Council of Copenhagen 1978: 5). After the Cold War, the growing number of applicant states from Central and Eastern Europe led the EU to set out more explicit requirements for membership. This resulted in the 1993 Copenhagen European Council stating that "Membership requires stability of institutions guaranteeing democracy, the rule of law, human rights and respect for and protection of minorities, a functioning market economy" (European Council of Copenhagen 1993: 13). Decisions concerning EU enlargement today are thus not random or arbitrary: the access of new countries is regulated by strict economic, democratic and political principles of conditionality which find concrete and legal groundings in EU official texts. In line with the category of "authorization" (Van Leeuwen 1996), the EU thus legitimates its enlargement policy by means of constant reference to the EU conditionality norms that regulate, endorse and 'authorise' the accession of new members:

(33) The Commission is carefully managing the accession process, ensuring that it is gradual and that countries are well prepared, over many years, to meet the EU's stringent conditions. (European Commission 2006a: 2)

(34) In 1993, the EU defined precise accession criteria. In order to join the EU, a country must be a stable democracy with the rule of law, able to respect human and minority rights, and have a competitive market economy, as well as the ability to fully implement EU law. (European Commission 2006a: 2)

(35) Bulgaria and Romania will enter in 2007 or 2008, once they meet the criteria. Croatia will follow some time later, once it fulfils all the conditions. (European Commission 2006a: 2)

Legitimation is also achieved through "rationalisation", whereby practices are justified "by reference to the goals and uses of institutionalized social action" (Van Leeuwen 2007: 92). The EU thus refers to the "utility" of its institutional practices, i.e. "to the purpose or function they serve, or the needs they fill, or the positive effect they will have" (Van Leeuwen and Wodak 1999: 105). Throughout the text, enlargement is 
constantly promoted and supported as the source of positive change, prosperity and reforms in a wide range of fields, from higher employment opportunities to increased environmental security:

(36) Recently, it [enlargement] has inspired tremendous reforms in Turkey, Croatia and the other Western Balkans countries. (European Commission 2006a: 1)

(37) A carefully managed enlargement process extends peace, democracy, the rule of law and prosperity across Europe. (European Commission 2006a: 1)

(38) By opening up opportunities for legal work in the old member states, the 2004 enlargement has helped to reduce the grey economy (and the black labour market). (European Commission 2006a: 6)

(39) Enlargement helps the EU to meet the challenge of globalisation by increasing internal and external trade and thus keeping and creating jobs. (European Commission 2006a: 7)

(40) By opening up a market of 75 million consumers to companies from the old member states, enlargement has strengthened competition in the internal market [...] (European Commission 2006a: 7)

(41) Therefore, enlargement gives us more control over the problem of clandestine migration. (European Commission 2006a: 14)

(42) Enlargement means more environmental security, not less. (European Commission 2006a: 11)

To conclude, the overall question/answer pattern adopted in the booklet " 20 Myths and Facts about Enlargement" (European Commission 2006a) enhances dialogism and "multivocality" (Bakhtin cited in De Fina et al. 2006: 12) and enables to compare different interpretations of the same experience: citizens' view vs. EU stance vis-à-vis enlargement. In particular, this discourse approach can be ascribed to what Van Dijk (1992) describes as the linguistic strategy of 'denial'. In order to counteract citizens' negative attitude towards the process, the question/answer format is instrumental to the argumentative denial of the implicit accusations as a way to express distance or non-acceptance of statements or accusations by others (Van Dijk 1992). Multivocality is in fact used by the European Commission to separate two different positions and distance itself from the indirect allegations on the catastrophic aftermath that citizens' questions may allude to (see examples 15-21). At the same time, this simulated 'face-toface' dialogue (Fairclough 1992: 98) is a way for the European Commission to 'control' the exchange and persuasively formulate its own opinion through a 'reversal of strategy' move: the negative scenario emerging from the questions is not only proven wrong, but also completely reversed by stating the exact opposite. Besides all the examples presented thus far, example number 43 below represents further evidence of a "reversal move" (Van Dijk 1992: 550). The negative scenario framed within the question (distorted competition) is overturned in the answer and exploited as a starting point to introduce an utterly positive situation (reinforced competition):

(43) Hasn't enlargement distorted the functioning of the internal market?

[...] By opening up a market of 75 million consumers to companies from the old member states, enlargement has strengthened competition in the internal market, which in turn also makes European companies more competitive on world markets. (European Commission 2006a: 7)

This reversal strategy also emerges from the booklet's title itself, in which citizens' "myths" are contrasted with the European Commission's "facts". This kind of move contributes to the overall strategy of legitimation and positive self-representation on the part of the institution. Implied accusations are rebutted through valid and self- 
evident claims, which are grounded on precise data and legitimated by the existence of a democratic and representative decision-making framework of reference.

\section{An ever closer and visual Europe}

The third document of the corpus of analysis, "Understanding enlargement" (European Commission 2007a), issued in 2007 after Romania and Bulgaria joined the EU, is distinctly different from the previous two in terms of general tone and visual impact.

The question-answer format which characterised the previous two booklets is here limited to two questions. Furthermore, the overall tone of the text reflects a more balanced Union-citizens relationship as it is seems to address a more informed and aware readership. The promotional function of the language used aims at reassuring the audience and highlighting the benefits that EU enlargement has and will bring about with the accession of new members:

(44) The 2004/2007 enlargement to countries from Central and Eastern Europe and the Mediterranean has proven a great success. (European Commission 2007a: 1)

(45) [...] today's EU with 27 Member States today's EU with 27 Member States and a population of close to 500 million people is much safer, more prosperous, stronger and more influential than the original European Economic Community of 50 years ago, with its 6 members and population of less than 200 million. (European Commission 2007a: 2)

(46) The EU has brought huge advantages to all Europeans. (European Commission 2007a: 5)

(47) But the EU is not just about wealth and improved standards of living. The EU is a community of values. We are a family of democratic European countries committed to working together for peace and freedom, prosperity and social justice. (European Commission 2007a: 4)

(48) The EU enlargement policy ensures a well managed accession process, so that enlargement brings benefits simultaneously to the EU and to the countries joining. (European Commission 2007a: 9)

The need to reassure citizens about further EU enlargement is pursued by underlining the importance of the principles of conditionality, which again reinforce the strategy of "legitimation through procedure" (Wodak and Weiss 2005) enacted in the previous document. In linguistic terms, conditionality is conveyed by locutions such as "If only", "only", "only after", "only when", "depend/s". In addition, the booklet encourages the idea that citizens are actively responsible for EU decisions through the voice of their elected political representatives:

(49) Membership will only happen when each one of them meets the necessary requirements. (European Commission 2007a: 1)

(50) In addition, the EU must be able to integrate new members, so it reserves the right to decide when it is ready to accept them. (European Commission 2007a: 6)

(51) New members are admitted with unanimous consent of the democratically elected governments of the EU Member States. (European Commission 2007a: 8)

(52) [...] candidate country's progress towards the EU depends on how well it implements reforms needed to fulfil the accession criteria. (European Commission 2007a: 14) 
(53) The EU should continue to grow at a pace to be determined by its own citizens and the progress of candidate countries in fulfilling the requirements. (European Commission 2007a: 16)

(54) Agreements with the countries of the Western Balkans or the Customs Union with Turkey - are reached only after the EU Member States have given their approval. (European Commission 2007a: 8)

(55) If the Commission delivers a positive opinion, and the Council unanimously agrees on a negotiating mandate, negotiations are formally opened between the candidate and all the Member States. (European Commission 2007a: 9)

The discursive strategies employed by the EU to build consensus and legitimacy around the enlargement process are here both verbal and visual. Indeed, out of the three documents being analysed, "Understanding enlargement" (European Commission 2007a) predominantly relies on the use of images to convey the institutional message and establish a communicative interaction with the citizens.

The foreword to the document by EU Commissioner for enlargement, Olli Rehn, is highly significant in this respect. The introductory text summarises the key issues being addressed in the document: historical overview of EU enlargement, description of the status quo and future perspectives of accepting new members. Interestingly enough, the EU Commissioner's words are accompanied by a close-up picture of him and his signature, both vouching for his personal commitment and conferring authoritativeness to what is being claimed. By doing so, legitimation strategies are once again deployed by the institutions and centred on the principle of "authorisation" (Van Leeuwen 2007: 91). In particular, when describing his "authorisation" category, Van Leeuwen (2007: 94) refers to "personal authority": "legitimate authority is vested in a person because of their status or role in a particular institution". Legitimation by reference to the authority and to "the persons in whom the institutional authority is vested" (Van Leeuwen 2007: 91) can again be found in the booklet with reference to the picture portraying all the democratically elected representatives of all EU governments:

\section{Figure 4: Political representatives of EU Member States}

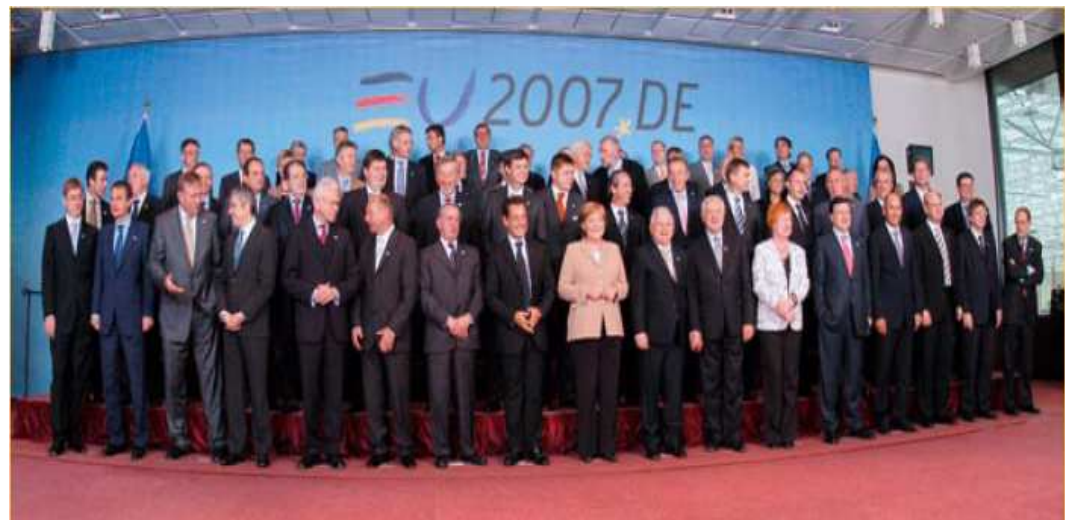

Source: “Understanding enlargement” (European Commission 2007a: 8).

Though crucial to the purpose of legitimation, authorities are not the only subjects being visually represented in the brochure. Among the pictures that complement and 'extend' the verbal text, there is a vast range of pictures depicting flags, countries and, above all, people. In analysing the semiotic value of these images, as well as the way the EU is representing its citizens, the analysis draws from Kress and Van Leeuwen's definition of "represented participants" (1996: 46): "participants who are the subject of the communication, that is, the people, places and things (including abstract 'things') represented in or by the speech or writing or image [...]". 
The emphasis on the human factor is an effective way to enhance readers' participation and identification with the choices made at a higher political level. Particularly significant is the picture of a very young girl (Figure 5) who is drawing the EU flag on the ground. The unfinished drawing suggests a message of 'futurity'. The image of the girl's feet, which still retain the blue colour for having walked over the drawing, hints at the possibility for citizens of moving easily throughout an enlarged Europe without barriers, as well as at the unfinished journey towards European integration.

\title{
Figure 5: Table of content image
}

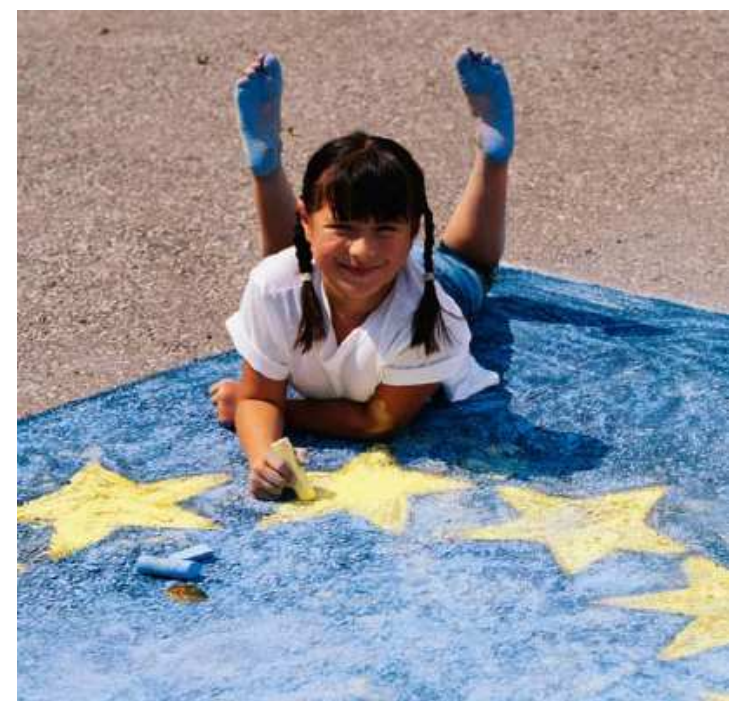

Source: “Understanding enlargement” (European Commission 2007a: 3).

People depicted in the brochure serve communicational purposes and are invested with the task of establishing a direct interaction with the reader. The dialogic and relational function played in the first two brochures by the question-answer format is here undertaken by the use of images: readers are being addressed by pictures of real individuals. The emerging 'human component' represents an attempt to step closer to the citizens and encourage their identification process. The photos are always closeups of the participants who are all portrayed at eye level angle, and so in a position of equality with the viewer they are addressing. According to the principles of visual grammar (Kress and Van Leeuwen 1996: 122):

\begin{abstract}
[...] the producer uses the image to do something to the viewer. It is for this reason that we have called this kind of image a 'demand': the participant's gaze (and the gesture, if present) demands something from the viewer, demands that the viewer enter into some kind of imaginary relation with him or her. Exactly what kind of relation is then signified by other means, for instance by the facial expression of the represented participants. They may smile, in which case the viewer is asked to enter into a relation of social affinity with them.
\end{abstract}

This device creates a projection and establishes an imaginary symmetrical relation between information givers and the audience. The EU delegates the delivery of its message to real people, soliciting a feeling of solidarity with the characters represented and so enhancing the 'credibility' of its final message.

The children's smiling faces (Figure 5 and 6), as well as the other faces that fill the brochure, are not geographically connoted. The reader's identification with these 'vectors' is also encouraged by the fact that they are representative of various social classes and age groups which makes them 'universally European', such as the little girl drawing the EU flag, the schoolboy, or other subjects being depicted in the booklet, 
like university students or factory workers. These people are the ones who have benefited and will benefit from EU enlargement and whose consent is fundamental for the admission of aspiring members. Citizens are thus active players in the development of European integration by sharing its values and accepting new members who, in turn, are prepared to work for a common future and fulfil the EU's requirements.

\section{Figure 6: The Future}

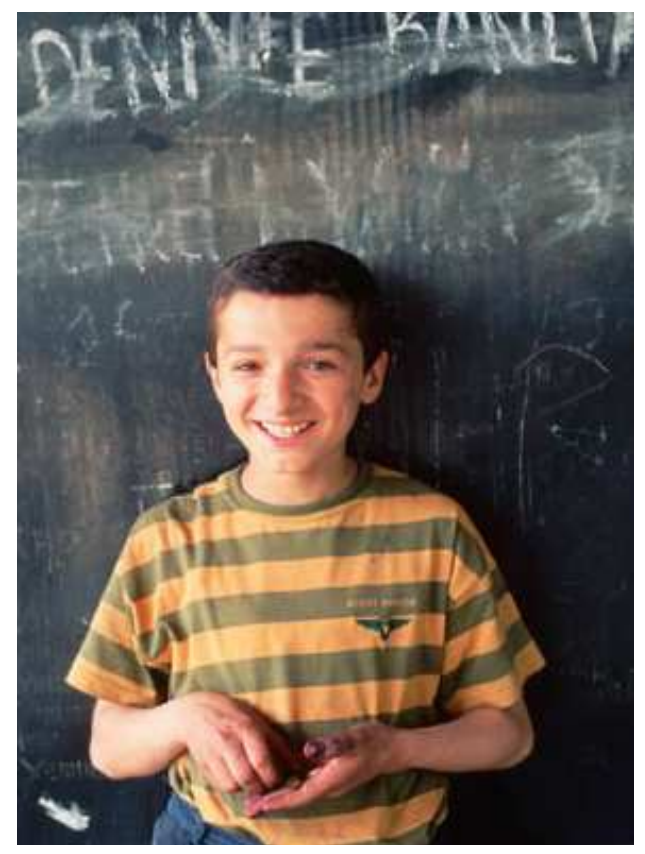

Source: “Understanding enlargement” (European Commission 2007a: 16).

In terms of visual metaphors, the image of the house which dominated the first booklet in 2004 is now replaced by recurring images recalling the semantic area of the family (Figure 7): children playing with their grandparents, children at school, elderly people and young couples. The ongoing journey of EU enlargement is here represented in its constant evolution, which calls into play the various generations of actors:

\section{Figure 7: Front cover}

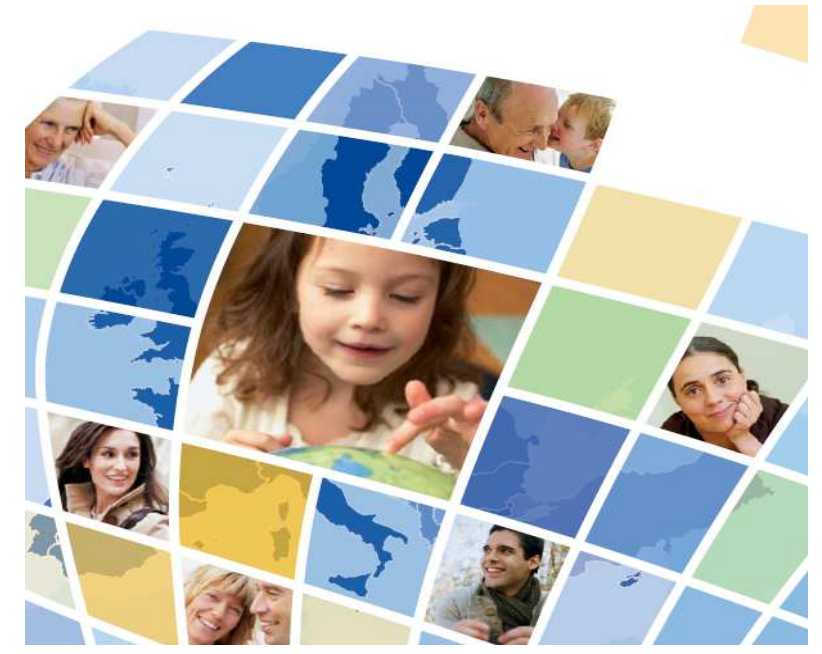

Source: “Understanding enlargement" (European Commission 2007a: front cover). 
On the booklet cover (Figure 7), images of EU citizens alternate with the geographical outline of EU countries. Member States are portrayed as if they were 'personified' and given a face within the wide and growing EU family and community. These ideas are also complemented by the verbal content of the brochure:

(56) The EU is a community of values. (European Commission 2007a: 5)

(57) We are a family of democratic European countries committed to working together for peace and freedom, prosperity and social justice. And we defend these values. We seek to foster cooperation among the peoples of Europe, while respecting and preserving our diversity. (European Commission 2007a: 5)

The diachronic evolution in the use of metaphors is particularly interesting in terms of the conceptualization of meaning. Laffan (2004: 83) underlines the salient role played by symbols and metaphors in the configuration of the cognitive dimension of the EU: "symbols constitute an important way in which new frames of meaning are constructed. Symbols connect individuals to the social and political order by providing orientations for interpreting the world". This idea is also stressed by Fairclough (1992: 194) in relation to discourse:

[...] metaphors are not just superficial stylistic adornments of discourse. When we signify things through one metaphor rather than another, we are constructing our reality in one way rather than another. Metaphors structure the way we think and the way we act, and our system of knowledge and belief, in a pervasive and fundamental way.

The passage from the static image of the house to the "motion metaphor" (Lakoff and Johnson 1980) of the family is aimed here at denoting the EU as a dynamic organism in constant evolution. The circular shape of the family is employed to suggest the idea of flexibility and openness. This association is also developed in sociological studies with reference to the idea of the EU as a network state that has nodes, not a centre: "The future, enlarged European Union must be less uniform and more flexible... It is possible that the organigram of such an institution will be closer to a network than to a tree, and political theory still does not have a simple term adequate to this kind of configuration, but it is not an obstacle to building it. However, it will not be enough that enlightened bureaucrats conceive this institution: it will also be necessary for the citizens to accept it" (Zaldivar, in Castells 2000: 362).

\section{Conclusion}

Public opinion and findings emerging from Eurobarometer polls have undoubtedly affected EU communication policies. In the light of widespread dissatisfaction on the part of the citizens regarding their role in influencing EU decisions, a number of official documents ${ }^{8}$ have recently highlighted the importance of adopting different strategies of dialogue.

It was in the wake of the first wave of EU enlargement that the institutions saw the need for a more direct contact with their citizens through the enactment of a series of new discursive practices. The EU thus came alive as a tangible entity willing to explain itself to Europeans with the precise intent of achieving legitimacy and consensus in relation to the enlargement process.

\footnotetext{
8 Among the most significant ones: European Commission (2006b), White Paper on a European Communication Policy. COM(2006) 35final; European Commission (2005a), Action Plan to Improve Communicating Europe by the Commission. Brussels; European Commission (2005b), The Commission's Contribution to the Period of Reflection and beyond: Plan D for Democracy, Dialogue and Debate. $\operatorname{COM}(2005)$ 494final.
} 
Our study has focussed on the linguistic, visual and pragmatic elements of EU communication in order to investigate the way in which enlargement is portrayed as an unprecedented and necessary political step which, for the good of 'us, Europeans', is crucial, positive as well as legitimate.

The analysis also suggests that, in describing and 'constructing' enlargement through discourse, the EU gradually moves away from a merely descriptive and informative stance and steadily veers towards 'authorisation' of its practices through a language which can be defined both as informative and strategic in Habermas' terms (1981), i.e. oriented towards an effective achievement of results. Indeed, all the publications examined feature varying traits of advertising discourse.

The first publication with the title "Enlarging the European Union: from 15 to 25, what does it mean to us?" (European Commission 2004) employs linguistic strategies which are typical of promotional discourse, mainly foregrounding the advantages of the enlargement and offering an optimistic and enthusiastic portrait of a 'bigger' and more integrated EU. The study also confirms Fairclough's theory on interdiscursivity (1995: 133-135), by which he refers to the "constitution of a text from diverse discourses and genres", and more specifically to the colonization of professional and public service orders of discourse by the genre of consumer advertising.

After the negative findings which emerged from the Eurobarometer polls undertaken in 2006, the EU communication with its citizens acquires a tone which is more typical of 'after sales' discourse. The question/answer format of the second booklet with the title "20 Myths and Facts about the Enlargement" (European Commission 2006a) proves an interesting linguistic device to give voice to citizens' concerns while effectively asserting and legitimating the EU voice, also through a more constant reference to the principle of conditionality.

In the third publication titled "Understanding enlargement" (European Commission 2007a), the discursive strategies of the EU acquire a new balance. In the booklet the EU resumes a more promotional discourse orientation, but also appears increasingly aware of the fact that its readership is more conscious both of the enlargement process and of their rights. The self-defensive tone of the second booklet gives way to a discourse aimed at gaining legitimation through procedure (Van Dijk 1997), while the presence of visuals becomes increasingly significant in the overall consensus-building process.

The analysis of the three publications confirms the CDA theory according to which discourse cannot be analysed in isolation from a wider social context as discourse practices construct (and are constructed) by social practices. The discursive construal of institutional reality thus does not obey top-down trends but rather serves the audience's needs for clarification, reassurance and involvement.

The process of change, especially in a shared social and institutional context, is inextricably related to the idea of acceptance. Legitimation thus plays a pivotal role in Union-to-citizen communication in order to reach a common understanding of what 'a new, enlarged Europe' is all about, which is paramount to the present and future coexistence of citizens. Consequently, with reference to the legitimation categories explored by critical discourse analysts, this study has not overlooked the way "receivers are managed into acceptance of the existing social [institutional] order as legitimate and even mobilized to actively support it" (Hamelink 1985: 152). In this respect, language plays a vehicular role in institutional discourse in order to legitimise controversial political actions and reinforce a common sense of belonging.

This contribution has also shown the ways in which visual images acquire increasing salience in institutional discourse. The small number of simple drawings in the first publication is replaced by a wider use of photographs portraying 'real Europeans', who are invested with the task of establishing a more authentic and direct relationship with 
the reader. Through their visual representation, citizens are given a face, and therefore a role, in the overall process. This fosters involvement and encourages identification with the 'human vectors' portrayed in the informative brochures.

Clearly, since the new neighbours have "entered the gate" (Caliendo and Balirano [forthcoming]) public interest and concerns need to be taken into account in reframing communities and boundaries. This delicate process necessarily implies rethinking the communicative instruments through which discourse creates and shapes a new reality. Inclusiveness and participation in the public sphere are also sought by means of new communication technologies, which play a major role in our case-study. The diffusion of informative material both in printed form and via the Internet testifies the rising interest and commitment on the part of the EU to gain consensus by reaching the greatest possible number of Europeans.

\section{References}

Berger, P. and Luckman, T. (1967). The Social Construction of Reality. A Treatise on the Sociology of Knowledge. Harmondsworth: Allen Lane the Penguin Press.

Caliendo, G. and Venuti, M. (2008). 'EU Discourse on Enlargement: the Negotiation of Meaning', in V. J. Bhatia et al. (eds.), The Formulation of Legal Concepts across Systems and Cultures. Bern: Peter Lang, pp. 207-221.

Caliendo, G. and Balirano, G. (forthcoming). 'Redrawing the Map of an Enlarged European Id-Entity: New Margins Stretching the Centre', in G. Di Martino et al. (eds.), Identity and Culture in English Domain-Specific Discourse: Practical and Methodological Issues. Naples: Edizioni Scientifiche Italiane.

Cap, P. (2005). 'Language and Legitimization: Developments in the Proximization Model of Political Discourse Analysis', Łódz Papers in Pragmatics, 1, pp. 7-36.

Castells, M. (2000). End of Millennium: The Information Age: Economy, Society and Culture. Malden, MA: Blackwell.

Charteris-Black, J. (2004). Politicians and Rhetoric. The Persuasive Power of Metaphor. Hampshire: Palgrave Macmillan.

Chilton, P. and Schäffner C. (1997). 'Discourse and Politics', in T. J. Van Dijk (ed.), Discourse as Social Interaction. Discourse Studies: A Multidisciplinary Introduction, volume 2, pp. 206-230.

Chilton, P. (2004). Analysing Political Discourse: Theory and Practice. London: Routledge.

DEBATE EUROPE online forum. Available at: http://europa.eu/debateeurope/index en.htm, last accessed December 2008.

De Fina, A., Schiffrin, D. and Bamberg, M. (2006). 'Introduction', in A. De Fina et al. (eds.) Discourse and Identity. Cambridge: Cambridge University Press, pp. 1-23.

EUROPA website. Available at: http://ec.europa.eu/enlargement/press corner/index en.htm, last accessed July 2008.

European Commission (2004). Enlarging the European Union: from 15 to 25, what does it mean to us? Available at: http://ec.europa.eu/enlargement/archives/pdf/press_corner/publications/key_i ssues from 15 to 25 en.pdf, last accessed December 2008.

European Commission (2005a). Action Plan to Improve Communicating Europe by the Commission. Brussels, 20 July 2005, available at:

http://ec.europa.eu/dgs/communication/pdf/communication_com_en.pdf, last accessed: December 2008.

European Commission (2005b). The Commission's Contribution to the Period of Reflection and beyond: Plan D for Democracy, Dialogue and Debate. COM(2005) 494final. Brussels, 13 October 2005. Available at: 
http://ec.europa.eu/commission barroso/wallstrom/pdf/communication plan

D_en.pdf, last accessed December 2008.

European Commission (2005c). Eurobarometer 62. Public Opinion in the European Union. Full Report. Fieldwork: October-November 2004. Available at: http://ec.europa.eu/public opinion/archives/eb/eb62/eb 62 en.pdf, last accessed December 2008.

European Commission (2006a). 20 Myths and Facts about the Enlargement. Available at: http://ec.europa.eu/enlargement/questions_and_answers/myths_en.htm, last accessed December 2008.

European Commission (2006b). White Paper on Communication Policy. COM (2006) 35 final. Brussels. Available at: http://europa.eu/documents/comm/white_papers/pdf/com2006_35_en.pdf ， last accessed December 2008.

European Commission (2006c). Special Eurobarometer. Attitudes Towards the European Union Enlargement. Available at:

http://ec.europa.eu/public opinion/archives/ebs/ebs 255 en.pdf, last accessed December 2008.

European Commission (2006d). Eurobarometer 64. Public Opinion in the European Union. Full Report. Fieldwork: October-November 2005. Available at:

http://ec.europa.eu/public opinion/archives/eb/eb64/eb64 en.pdf, last accessed December 2008.

European Commission (2007a). Understanding Enlargement. Available at: http://ec.europa.eu/enlargement/pdf/publication/enl-understand_en.pdf, last accessed December 2008.

European Commission (2007b). Eurobarometer 66. Public Opinion in the European Union. Full Report. Fieldwork: October-November 2006. Available at: http://ec.europa.eu/public_opinion/archives/eb/eb66/eb66_en.pdf, last accessed December 2008.

European Council of Copenhagen (1978). European Council Conclusions. Declaration on Democracy, 11 EC Bulletin No. 3 (8 April 1978).

European Council of Copenhagen (1993). European Council Conclusions, EC Bulletin No. 6 (21-22 June 1993).

European Union (2004). Treaty Establishing a Constitution for Europe, Official Journal of the European Union, C 310, volume 47 (16 December 2004).

Fairclough, N. (1989). Language and Power. London: Longman.

Fairclough, N. (1992). Discourse and social change. Cambridge: Polity Press.

Fairclough, N. (1994). 'Conversationalization of public discourse and the authority of the consumer', in R. Keat et al. (eds.), The Authority of the Consumer. Routledge. New York, pp 253-268.

Fairclough, N. (1995). Critical Discourse Analysis: the critical study of language. London, Longman.

Habermas, J. (1976). Legitimation Crisis. London: Heinemann.

Habermas, J. (1981). Theorie des kommunikativen Handelns, Band 1: Handlungsrationalität und gesellschaftliche Rationalisierung Band 2: Zur Kritik der funktionalistischen Vernunft. Frankfurt a.M.: Suhrkamp Verlag.

Hamelink, C. J. (1985). 'International Communication', in T. J. Van Dijk, Discourse and Communication. New Approaches to the Analysis of Mass Media Discourse and Communication. Berlin/New York: Walter de Gruyter, pp. 143-155.

Jaworski, A. and Coupland, N. (2006). 'Perspectives on Discourse Analysis', in A. Jaworski and N. Coupland (eds.), The Discourse Reader. London: Routledge, pp. 1-44.

Karklins, R. (2001). 'The Concept of Collective Identity', in Proceedings of the Colloquy of the Council of Europe "The Concept of Identity", 17-18 April 2001. Strasbourg, available http://www.coe.int/T/E/Com/Files/Themes/Identity/e disc karklins.asp, last accessed: December 2008.

Kress, G. and Van Leeuwen, T. J. (1996). Reading Images - The Grammar of Visual Design. London: Routledge. 
Krzyżanowski, M. (2005). "'European identity wanted!" On discursive dimensions of the European Convention', in R. Wodak and P. Chilton (eds.), A New Agenda in (Critical) Discourse Analysis: Theory, Methodology and Interdisciplinarity. Amsterdam: Benjamins, pp. 137-163.

Krzyzanowski, M. and Oberhuber, F. (2007). (Un)doing Europe: discourses and practices of negotiating the EU constitution. Bern: P.I.E. Peter Lang.

Laffan, B. (2004). 'The European Union and Its Institutions as "Identity Builders"', in R. K. Herrmann et al., Transnational Identities. Becoming European in the EU. Oxford: Rowman \& Littlefield, pp. 75-96.

Lakoff, G. and Johnson, M. (1980). Metaphors We Live By. Chicago and London: The University of Chicago Press.

Phillips, L. and Jorgensen, M. W. (2002). Discourse Analysis as Theory and Method. London: Sage.

Shortis, T. (2001). The Language of ICT. London: Routledge.

Treaty establishing the European Economic Community. (1957), available at: http://eur-lex.europa.eu/en/treaties/index.htm\#founding, last accessed: December 2008.

Van Dijk, T. A. (1992). 'Discourse and the Denial of Racism', Discourse \& Society 3(1), pp. 87-118.

Van Dijk, T. A. (ed.) (1997). Discourse studies: A multidisciplinary introduction. London: Sage Publications.

Van Leeuwen, T. J. (1996). 'The Representation of Social Actors', in C. R. CaldasCoulthard and M. Coulthard (eds.), Texts and Practices - Readings in Critical Discourse Analysis. London: Routledge, pp. 32-70.

Van Leeuwen, T. J. (2007). 'Legitimation in discourse and communication', Discourse \& Communication, Vol. 1, pp. 91-112.

Van Leeuwen, T. J. and Wodak, R. (1999). 'Legitimizing Immigration Control: A Discourse-Historical Analysis', Discourse Studies 1, pp. 83-118.

Weber, M. (1964). The Theory of Social and Economic Organization. New York: The Free Press.

Wodak, R. and Weiss, G. (2004). 'Visions, Ideologies and Utopias in the Discursive Construction of European Identities: Organizing, Representing and Legitimizing Europe', in M. Pütz et al. (eds.), Communicating Ideologies. Multidisciplinary Perspectives on Language, Discourse, and Social Practice. Frankfurt/Main: Peter Lang, pp. 225-252.

Wodak, R. and Weiss, G. (2005). 'Analyzing European Union discourses: theories and applications', in R. Wodak and P. Chilton (eds.), A New Agenda in (Critical) Discourse Analysis. Amsterdam: Benjamins, pp. 121-136. 